\title{
UPAYA GURU MENGEMBANGKAN KREATIVITAS ANAK PRA SEKOLAH MELALUI MEDIA PLAYDOUGH DIKELOMPOK B KOBER MIFTAHUL FALAH
}

\author{
Yayu Rahayu $^{1}$, Yeni Heryani ${ }^{2}$ \\ ${ }^{1}$ TK Dharma Kartini \\ ${ }^{2}$ Kober Miftahul Falah \\ ${ }^{1}$ Tk.dharma.kartini.2@gmail.com, ${ }^{2}$ yeniheryani05@gmail.com
}

\begin{abstract}
Creativity has a very important role in the lives of children. Through kerativitas, children can be creative in accordance with the talent or ability, the child can solve a problem and can improve the quality of life in the future. Therefore, stimulation is needed that can develop the creativity of children, one of them through mengguanaan media playdough. In early childhood creativity has not developed well, early childhood has not been smooth in expressing idea idea idea. The purpose of this assessment is to describe the level of early childhood creativity by applying playdough media, differences in early childhood creativity levels before and after applying media playdough. Methods used in this study are classroom action research methods (PTK). The subjects of this study were children aged 4-5 years kober miftahul falah which amounted to 14 children consisting of 9 women and $5 \mathrm{men}$. The results of this study indicate a positive impact in improving creativity of children by $25.83 \%$ based on evaluation results from cycle I and cycle II.Dengan, it can be concluded that the media playdough provide a significant influence. So that can be recommended for teachers to use media playdough can be used as an alternative to develop creativity in children effectively. For schools to be able to facilitate by providing other learning media that can enhance the creativity of young children.
\end{abstract}

Key Words: Playing playdough, creativity

\begin{abstract}
ABSTRAK
Kreativitas mempunyai peran yang sangat penting untuk kehidupan anak. Melalui kerativitas, anak dapat menjadi kreatif sesuai dengan bakat ataupun kemampuan, guru perlu menstimulasi anak untuk dapat mengembangkan kreativitas anak, diantaranya melalui pengguanaan media playdough. Dalam kreativitas anak usia dini belum berkembang dengan baik, anak usia dini belum lancar dalam mengungkapkan ide tau gagasan. Tujuan dalam penilaian ini adalah untuk mendeskripsikan tingkat daya kreasi pada usia Taman Kanak-Kanak dengan menerapkan media playdough, perbedaan tingkat daya kreasi pada usia Taman Kanak-Kanak sebelum dan sesudah menerapkan media playdough. Metode yang di pakai untuk penelitian ini adalah metode penelitian tindakan kelas (PTK). Subjek penelitian ini yaitu anak kelompok A kober miftahul falah yang berjumlah 14 orang anak terdiri dari 9 orang perempuan dan 5 orang laki-laki. Hasil penelitian ini menunjuakan dampak positif dalam mengembangkan daya kreasi anak sebesar 25,83\% berdasarkan evaluasi hasil dari siklus I dan siklus II. Dengan demikian, bisa dibuat kesimpulan bahwa media playdough memberikan pengaruh yang signifikan.Sehingga dapat direkomendasikan bagi guru untuk penggunaan media playdough bisa dipakai sebagai alternative untuk mengembangkan kreativitas pada anak secara efektif. Bagi sekolah agar dapat memfasilitasi dengan menyediakan media pembelajaran bisa mengembangkan kreativitas pada anak secara efektif.
\end{abstract}

Kata kunci : Bermain playdough, kreativita 


\section{JURNAL GERIA}

ISSN : 2614-6347 (Print) 2614-4107 (Online)

\begin{tabular}{l|l|l} 
Vol.2 & No.1 & Januari 2019
\end{tabular}

\section{PENDAHULUAN}

Anak merupakan generasi penerus bangsa yang berlangsung secara terus menerus dan bersifat alami. Dari generasi kegenerasi masyarakat suatu bangsa akan mengalami pertumbuha yang berbeda karena pengetahuan dan pengalaman pembelajaran dimilikinya sangat berbeda pula. Masyarakat memiliki ilmu dan pengetahuan yang baik tentu saja akan membuat generasi yang baik pula, begitu pun sebalik. Salah satu indicator yang menentukan kualitas suatu generasi masyarakat ditentukan oleh pendidikan yang diperoleh baik itu melalui pendidikan formal mauoun non formal. Peletakan dasar untuk pengembangkan piker dan kepribadian pra sekolah sangat ditentukan buat proses pembelajaran yang diberikan oleh orang tua sejak anak-anak masih berusia berusia prasekolah 0-6 tahun.

Pengalaman yang didapat oleh usia pra sekolah melalui pendidikan belajar di lingkungan keluarga, lingkungan masyarakat, maupun lingkungan kelompok bermain dan Taman Kanak-kanak merupakan suatu pembelajaran yang berharga untuk pengembangan kedepan.pikir anak.

Pelaksanan pendidikan Anak Usia Dini (PAUD) diselenggarakan dengan memberikan fasilitas media yang disesuaikan dengan tahap belajar anak. Proses belajar pada PAUD ditentukan oleh kemajuan proses belajar dan proses berimajinasi yang sesuai dengan kemampuan yang dimiliki oleh usia pra sekolah. Diantaranya proses yang penting yang dibutuhkan oleh anak pra sekolah adalah meningkatkan daya kreasi.

(Rachmawati, 2011)memaparkan bahwa daya kreasi merupakan keunggulan anak untuk menciptakan sesuatu yang berbeda, bias berupa berupa gagasan ataupun hasil karya berbeda dengan hasil yang telah ada sebelumnya. Sementara itu, (Rachmawati, 2011)mengemukakan bahwa kreativitas merupakan proses ental yang unik, suatu proses yang semata-mata dilakukan untuk menghasilkan sesuatu yang berbeda dan orisinil. Daya cipta akan tumbuh pada anak yang mempunyaimotivasi tinggi, rasa ingin tahu, dan imajinasi, individu yang kreatif akan mencari dan mengemukakan jawaban dalam memecahakan masalah selalu bersikap terbuka terhadap sesuatu yang baru dan tidak diketahui sebelumnya serta memiliki sikap yang lentur (fleksibel), suka mengekspresikan diri dan sikap natural (asli).

Menurt Munandar (1985), mengatakan kreativitas sebagai bahan penghubung dengan penemuan sesuatu, membuat sesuatu yang baru, daripada akumulasi keterampilan atau berlatih pengetahuan dalam mempelajari buku.

Berdasarkan beberapa definisi di atas dapat kita simpulkan bahwa daya kreasi adalah suatu proses mental individu yang menumbuhkan ide-ide, proses, teknik ataupun produk baru yang efektif yang bersifat imajinatif, estetis, fleksibel, integrasi, suksesi, diskontinuitas, dan diferensiasi yang berdaya guna untuk berbagai bidang dalam pemecahan suatu masalah.

(Eliyawati, 2005)menyatakan bahwa alat peraga adalah alat untuk menyampaikan materi pendidikan seperti bacaan, film, video, slide, dan lainlain.Contoh media tersebut dapat dikatakan sebagai media pelajaran untuk membawa pesan-pesan dalam rangka mencapai tujuan pendidikan. Berdasarkan pengertian tersebut dapat disimpulkan bahwa alat peraga merupakan media atau bahan yang digunakan oleh sumber pesan/guru sebagai alat komunikasi untuk menyampaikan pesan atau materi pendidikan kepada penerima pesan atau siswa seperti: buku, film, video, dan sebagainya. Media playdough merupakan salah satu permainan edukatif karena dapat mendorong imajinasi anak(Eion, 2002).Definisi playdugh yang diutarakan(Eion, 2002) adalah suatu bahan yang lembut, dapat membuat anak-anak terdiam cukup lama ketika mengerjakannya, walaupun bermacammacam seperti warna pelangi dan kotorannya dapat mmenempel di karpet. Lebih lanjut (Nichols, 2010) menjelaskan bahwa playdough merupakan salah satu permainan edukatif yang mudah digunakan oleh anak, multiguna, murah dan mudah mendapatkannya, aman tidak 


\section{JURHAL GERIA}

ISSN : 2614-6347 (Print) 2614-4107 (Online)

\begin{tabular}{l|l|l} 
Vol.2 & No.1 & Januari 2019
\end{tabular}

membahayakan, awet dan tahan lama, dapat digunakan individu atau klasikal, warna menarik dapat dikombinasikan, memiliki kesesuaian ukuran, serta elastis dan ringan.

Berdasarkan permasalahan diatas penulis ingin mencoba menggunakan kegiatan playdough untuk pengembangan kreativitas pada anak, karena pada saat kegiatan playdough anak bisa membuat daya ciptasesuai dengan daya imajinasi anak masing-masing dan kegiatan playdough menarik bagi anak. Dengan demikian penelitian ini berjudul" Upaya guru mengembangkan kreativitas anak pra sekolah melalui kegiatan playdough di keiompok B kober miftahul falah" .

\section{METODE}

Penelitian ini memakai penelitian tindakan kelas (classroom Action Research). Penelitian tindakan kelas adalah suatu pencermatan pada kegiatan yang sengaja dimunculkan dan terjadi dalam sebagian kegiatan. Menurut (Arikunto, n.d.)penelitian tindakan kelas merupakan suatu pencerminan pada kegiatan pembelajaran merupakan sebuah tindakan yang sengaja dimunculkan dan terjadi dalam sebuah pembelajaran secara bersamaan.Penelitian tindakan kelas memiliki tujuan untuk mengoreksi dan mendapatkan praktik pembelajaran di kelas secara bergantian dimana guru secara

Lokasi penelitian ini bertempat di kober miftahul falah $\mathrm{kp}$. Cibuntu $\mathrm{rt} / \mathrm{rw}$ 001/002 kec.Cipeundeuy kab.Bandung barat. Subjek penelitian ini adalah usia pra sekolah yang berjumlah 14 orang, tahun pelajaran 2017/2018 yang terdiri dari 9 orang anak perempuan dan 5 orang anak laki-laki. Dipilih kober miftahul falah dikarenakan berdasarkan hasil pengamatan di kelas banyak anak yang belum mampu dalam berkreativitas.

Pengumpulan data ini diperoleh data berupa observasi dan dokumentasi.I nstrument yang di gunakan adalah lembar observasi aktivivitas guru, lembar observasi peningkatan kreativitas anak mengacu pada RKM dan RKH yang telah di rancang.Pengamatan dilakukan selama kegiatan berlangsung.Pada observasi ini dilaksanakan dengan teman sejawat. Teknik analisis data menggunakan statistic deskriptif dilaksanakan pada awal penelitian pertama dari pengamatan, perencanaan tindakan, pelaksanaan sampai refleksi terhadaptindakan yang dilakukan.

\section{HASIL DAN PEMBAHASAN \\ Hasil}

Berdasarkan hasil penelitian maka dapat disimpulkan bahwa permainan playdough dapat meningkatkan kreativtas anak pada kelompok usia pra sekolah di kober miftahul falah, pada siklus I kemampuan untuk meningkatkan kreativitas anak belum berhasil memenuhi tingkat keberhasilan yaitu $75 \%$, hal ini dapat dilihat dari lembar observasi guru pada siklus I pada pertemuan 1 sebesar $58,3 \%$ meningkat, dalam pertemuan 2 menjadi 70,83\%. Pada kertas observasi aktivitas anak siklus I pertemuan 1 sebesar $54,16 \%$ naik menjadi $66,66 \%$ pada pertemuan 2 dalam penilaian peningkatan kreativitas anak pertemuan 1 sebesar $55,27 \%$ meningkat menjadi $68,61 \%$ pada pertemuan 2. Sehingga kemampuan berkreativitas pada siklus I belum sama yang diharapkan dan perlu adanya perbaikan pada siklus II.

Pada siklus II ini menunjukan bahwa siklus sudah tidak dilanjutkan lagi karena sudah memenuhi criteria keberhasilan sebesar 75\% mendapat nilai bintang 3 dan bintang 5, hal ini dapat dilihat dari lembar observasi aktivitas guru pada siklus II pada pertemuan 1 sebesar $88,5 \%$ meningkat sebesar $99 \%$ pertemuan 2 dan lembar observasi aktivitas anak pada siklus II pada pertemuan 1 sebesar $80,16 \%$ meningkat sebesar $91,66 \%$ pertemuan 2 sedangkan penilaian pengembangan daya kreasi anak pertemuan 1 sebesar $85,38 \%$ meningkat menjadi $94,43 \%$ pada pertemuan 2. Berdasarkan uraian diatas maka pembelajaran di siklus II sudah tidak dilakukan karena sudah memasuki target yang ditetapkan.

\section{Pembahasn}

Dalam proses pembelajaran siklus I masih ada hal-hal yang harus dikoreksi diantaranya dalam mengkondisikan anak dan cara guru menjelaskan bagaimana cara 


\section{JURNAL GERIA}

ISSN : 2614-6347 (Print) 2614-4107 (Online)

\begin{tabular}{l|l|l} 
Vol.2 & No.1 & Januari 2019
\end{tabular}

bermain playdough dalam proses belajar berlangsung guru harus mendampingi dan mendorong anak. Pada siklus I kemampuan anak untuk mengembangkan daya cipta anak belum mencukupi criteria kesuksesan sebanyak $76 \%$ ini dilihat dari hasil observasi aktivitas guru pada siklus I mendapat $71,83 \%$, lembar observasi kreatifitas murid $65,66 \%$ juga penilaian pengembangan daya cipta murid sebesar $67,61 \%$ sehingga pembelajaran meningkatkan kreativitas anak dalam bermain playdough belum sesuai yang diharapkan.

Kegagalan siklus I dikarenakan pendidik dalam memberikan pelajaran bermain playdough kurang disenangi dan dipahami muridCuma membentuk bulatanbulatan saja dan saat merecalling tidak menyenangkan sehingga membuat anak tidak maksimal untuk memperhatikan, mendengar dan bermain playdough serta menjawab pertanyaan guru. Pada siklus II peneliti mencoba memperbaiki segala kekurangan dalam pembelajaran dengan cara merevisi kegiatan bermain ke dalam bentuk permainan untuk lebih beragam juga menarik untuk anak, guru membuka kegiatan dengan apersepsi, menyampaikan materi tentang playdough, mendampingi, membimbing dan member motivasi anak agar lebih optimal dalam mengembangkan kreativitas anak dalam bermain playdough. Keberhasilan metode pembelajaran pada siklus II ini menunjukan bahwa pada siklus II sudah boleh dihentikan karena sudah mencukupi criteria keberhasilan sebesar $75 \%$ dari 14 anak yang diteliti yaitu dalam lembar observasi guru mencapai $100 \%$, lembar observasi anak sebesar $92,66 \%$ juga penilaian pengembangan daya kreasi anak sebesar $95.43 \%$. pada observasi ini aktivitas pendidik berkembang sebesar $29,17 \%$, pada aktivitas anak berkembang sebesar $26 \%$ dan penilaian pengembangan kreativitas sebesar $26,83 \%$ melalui bermain playdough.

Hasil penelitian waktu anak bermain, anak mengerti dan mengin segala sesuatu yang ada dilingkungan sekitarnya. Oleh sebab itu, perancangan dan pembuatanlingkungan belajar anak harus ditata dengan seksama sehingga segala hal akan menjadi kesempatan belajar yang snagat menyenangkan.

\section{SIMPULAN}

Perkembangan anak untuk mengembangkan daya kreatif anak dalam bermain playdough pada siklus I mendapatkan nilai sebesar $67,61 \%$ pada siklus II mendapatkan nilai sebesar $94,43 \%$. Melalui bermain playdough anak berkeinginan dan merasa bahagia untuk mengikuti metode pembelajaran. Dengan demikian, dapat dinyatakan bahwa melalui bermain playdough dapat meningkatkan kreativitas pada anak kelompok usia 4-5 tahun kober miftahul falah dapat dikatakan meningkat dengan baik. Bersumber dari observasi yang sudah disimpulkan diatas dan dalam upaya meningkatkan kreativitas anak dapat meningkat dengan baikpada anak usia pra sekolah di kober miftahul falah, dikemukakan beberapa saran sebagai berikut bahwa melalui bermain playdough dapat menarik minat anak dalam berkreativitas dan sebaiknya guru juga memperbanyak reperensi yang lain dan kegiatan yang lebih bervariasi dalam meningkatkan kreativitas anak dalam bermain playdough.

\section{DAFTAR PUSTAKA}

Arikunto, S. (n.d.). penelitian tindakan kelas.

Eion. (2002). Anak Kreatif. Batam: Karisma Publising Group.

Eliyawati. (2005). Pemilihan dan Pengembangan Sumber Pelajar untuk Anak Usia Dini. Jakarta: Departemen Pendidikan Nasional.

Munandar. (1985). Mengembangkan Bakat dan Kreativitas Anak Sekolah. Jakarta: Gramedia.

Nichols, B. (2010). Bagaimana Meningkatkan Pengembangan Playdough Bayi itu?

Rachmawati, Y. (2011). Strategi Pengembangan kreativitas pada Anak Usia Taman Kanak-kanak. Jakarta: Kencana. 